\title{
Drying of Albedo and Whole Peel of Yellow Passion Fruit
}

\author{
E. C. O. da Silva ${ }^{1}$, W. P. da Silva ${ }^{2}$, J. P. Gomes ${ }^{1}$, C. M. D. P. S. Silva ${ }^{2}$, H. V. Alexandre ${ }^{1}$, V. S. O. Farias ${ }^{2}$, \\ B. A. de Melo ${ }^{1}$, A. J. M. Queiroz ${ }^{1} \&$ R. M. F. de Figuiredo ${ }^{1}$ \\ ${ }^{1}$ Department of Agricultural Engineering, Federal University of Campina Grande, Campina Grande, PB, Brazil \\ ${ }^{2}$ Department of Physics, Federal University of Campina Grande, Campina Grande, Cuité, PB, Brazil \\ Correspondence: Wilton Pereira da Silva, Department of Physics, Federal University of Campina Grande, R. \\ Aprígio Veloso, 882, Campina Grande, PB, Brazil. Tel: 55-839-692-7630. E-mail: wiltonps@uol.com.br
}

Received: March 5, 2019

Accepted: April 4, 2019

Online Published: May 15, 2019

doi:10.5539/jas.v11n6p501

URL: https://doi.org/10.5539/jas.v11n6p501

The research is financed by Conselho Nacional de Desenvolvimento Cientifico e Tecnológico-CNPq.

\begin{abstract}
The use of waste has been the focus of attention of the agri-food sector, and a fruit with large amount of waste is the passion fruit. Its peel consists of albedo and flavedo, which can be used to manufacture flour, and some studies propose the need to remove the flavedo as well as to perform maceration. The objective of the present work was to study the drying process to produce flour from passion fruit albedo and whole peel, checking the influences of the flavedo removal and maceration steps, as well as the drying temperatures $\left(70\right.$ and $\left.80{ }^{\circ} \mathrm{C}\right)$. Yield after drying was calculated and it was shown to be low. Page, Silva et alii, Henderson and Pabis and Logarithmic mathematical models were fitted to the experimental data using LAB Fit software. The statistical indicators used to identify the best fit were coefficient of determination $\left(\mathrm{R}^{2}\right)$ and chi-square $\left(\chi^{2}\right)$. The Page model was the one that fitted best to the data, showing the best statistical indicators. Also, it can also be highlighted that the sample composed of peel without maceration and dried at $70^{\circ} \mathrm{C}$ had the best results regarding the statistical indicators.
\end{abstract}

Keywords: waste use, Passiflora edulis f. Flavicarpa, flour

\section{Introduction}

Yellow passion fruit (Passiflora edulis) is among the agricultural products with wide popular acceptance and large quantity of wastes. Its peel represents almost all the waste and is composed of albedo (white part) and flavedo (yellow part). In general, in order to use passion fruit peel in food production, the material is macerated (immersed in water), a procedure which aims to reduce the bitter taste caused by the substance naringin present in its composition (Dias et al., 2011; Yamashita, 2017).

One of the alternative processes that can be used to reduce passion fruit wastes is drying, which can be carried out using artificially moved air, followed by flour production, which can be used in the formulation of other various types of food (Di Domenico et al., 2017; Machado et al., 2013).

Drying allows the determination of the drying kinetics, which tries to define the behavior of the dried solid material and depends on its specific properties, temperature, drying air speed and relative air humidity, represented by the drying curves and drying rate. Depending on the material to be dried, the drying process may require a very long time, which makes it difficult to obtain data for drying kinetics determination. Thus, mathematical simulation becomes fundamental to describe such behavior (Silva et al., 2015; Di Domenico \& Conrad, 2015).

Given the above, this study aimed to conduct drying experiments at different temperatures using passion fruit albedo and whole peel with and without maceration, checking the influence of flavedo removal and maceration on the production of flour, besides calculating the mass yield of the samples after the process.

\section{Material and Methods}

Approximately 600 passion fruits (Passiflora edulis f. Flavicarpa) were purchased in the Paraíba state, at full maturity stage (completely yellow peel). Initially, the passion fruits were washed in running water and immersed 
in sodium hypochlorite solution ( $50 \mathrm{ppm}$ ) for $5 \mathrm{~min}$, then washed again in running water to remove the sanitizing solution.

The passion fruits were cut in half and their pulp was removed. Then, $50 \%$ of the peels were cooked for 5 min to facilitate the removal of flavedo (yellow part). The albedo and resulting peels were divided into two equal parts, only one of which underwent the step of maceration.

Maceration was carried out by following the method described by Dias et al. (2011), in which the material was immersed in water for $24 \mathrm{~h}$ at a proportion of $400 \mathrm{~g}$ of sample for every $2 \mathrm{~L}$ of water at room temperature $\left(25 \pm 1^{\circ} \mathrm{C}\right.$ ). The samples were then chopped in a food processor (Figure 1(a)) to uniformize the size of fragments and facilitate the subsequent drying process.

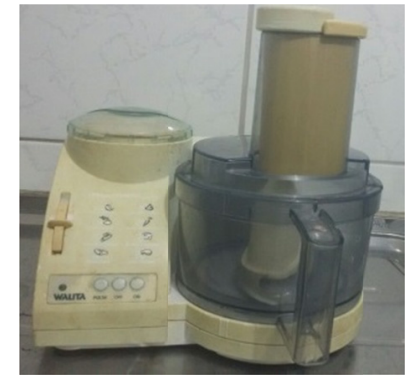

(a)

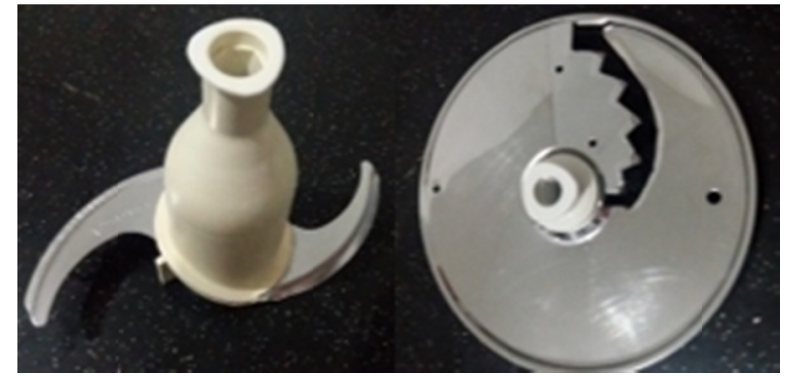

(b)

Figure 1. (a) Food processor; (b) Blades used to chop the samples

The albedo was chopped with an S-blade as shown in Figure 1(b), whereas the peels, for not having been cooked, had a more rigid surface and hence had to be initially reduced with the second blade shown in Figure 1(b) before being chopped with the S-blade.

Figure 2 shows the configuration of the peels after being cut with a knife (Figure 2(a)), chopped with the first blade (Figure 2(b)) and finally chopped with the S-blade (Figure 2(c)).

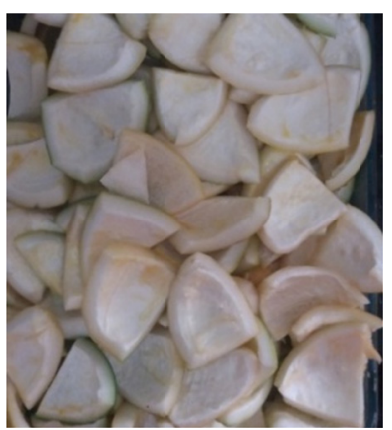

(a)

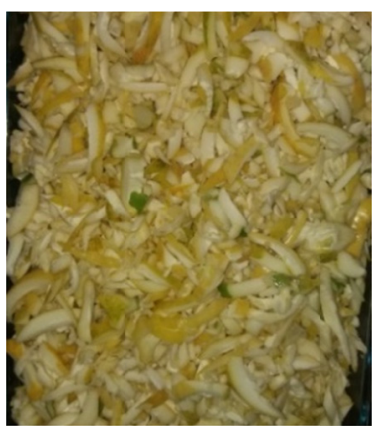

(b)

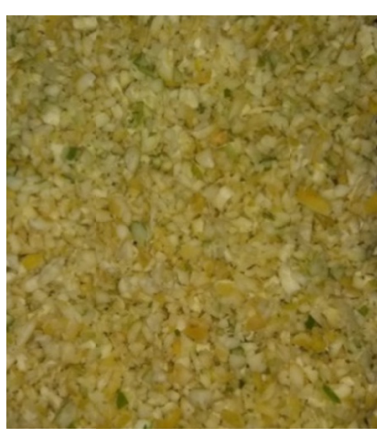

(c)

Figure 2. Configurations of passion fruit peel during the chopping process: (a) initial; (b) intermediate; (c) final

Then, the samples were placed in polypropylene plastic bags, frozen at $-18 \pm 1{ }^{\circ} \mathrm{C}$ and kept under such condition until $24 \mathrm{~h}$ before the experiments, when they were then transferred to the refrigerator to thaw.

For drying and obtaining the flour, the samples were thawed at temperature of approximately $5{ }^{\circ} \mathrm{C}$ for 24 hours and only then subjected to drying.

Drying tests were conducted in triplicate in a mechanical air circulation oven (320E model, Fanem, SP, Brazil), at temperatures of 70 and $80 \pm 1{ }^{\circ} \mathrm{C}$. An average mass of $800 \mathrm{~g}$ of the thawed waste was weighed on a tray with the material distributed in such a way to form a layer of approximately the same thickness, allowing the drying process to occur as uniformly as possible, until there was no significant variation in the sample mass. The experimental data were expressed in the form of moisture ratio $\left(\mathrm{X}^{*}\right)$ using Equation 1. 


$$
\mathrm{X}^{*}=\frac{\mathrm{X}_{\mathrm{t}}-\mathrm{X}_{\mathrm{e}}}{\mathrm{X}_{\mathrm{o}}-\mathrm{X}_{\mathrm{e}}}
$$

where, $\mathrm{X}_{\mathrm{t}}$ : moisture content at time $\mathrm{t}$, dry basis, d.b.; $\mathrm{X}_{\mathrm{e}}$ : equilibrium moisture content, d.b.; $\mathrm{X}_{\mathrm{o}}$ : initial moisture content, d.b.

Drying kinetics was described using the nonlinear regression models presented in Table 1 . The equations of the models were used for treatment and fitting of the experimental data using LAB Fit Curve Fitting Software.

Table 1. Models used to describe passion fruit flour drying kinetics

\begin{tabular}{lll}
\hline Name of the model & Equation & Reference \\
\hline Page & $\mathrm{X}^{*}=\exp \left(-\mathrm{at}^{\mathrm{b}}\right)$ & Page (1949) \\
Silva et alii & $\mathrm{X}^{*}=\exp \left(-\mathrm{at}-\mathrm{bt}^{0.5}\right)$ & Silva et al. (2014) \\
Henderson and Pabis & $\mathrm{X}^{*}=\mathrm{a} \cdot \exp (-\mathrm{bt})$ & Henderson and Pabis (1961) \\
Logarithmic & $\mathrm{X}^{*}=\mathrm{a} \cdot \exp (-\mathrm{bt})+\mathrm{c}$ & Yaldiz et al. (2001) \\
\hline
\end{tabular}

Note. $\mathrm{t}$ : drying time, min; $\mathrm{a}, \mathrm{b}$ and $\mathrm{c}$ : model parameters.

The evaluation criteria used to identify the best fit of the models to the experimental data were the determination coefficient $\left(\mathrm{R}^{2}\right)$ and Chi-square $\left(\chi^{2}\right)$, calculated by Equation (2):

$$
\chi^{2}=\frac{\sum_{\mathrm{i}=1}^{\mathrm{N}}\left(\mathrm{X}_{\mathrm{exp}, \mathrm{i}}^{*}-\mathrm{X}_{\mathrm{pre}, \mathrm{i}}^{*}\right)^{2}}{\mathrm{~N}-\mathrm{n}}
$$

where, $\chi^{2}$ : chi-square; $\mathrm{X}_{\text {exp, } \mathrm{i}}^{*}$ : experimental moisture ratio; $\mathrm{X}_{\text {pre, } \mathrm{i}}^{*}$ : moisture ratio predicted by the model; $\mathrm{N}$ : number of experimental data; $n$ : number of coefficients and constants of the model.

Finally, eight samples were collected for physical-chemical analysis, as shown in Table 2.

Table 2. Nomenclature adopted for the samples after drying

\begin{tabular}{llll}
\hline & Drying temperature $\left({ }^{\circ} \mathrm{C}\right)$ & With maceration & Without maceration \\
\hline \multirow{2}{*}{ Albedo } & 70 & MA70 & A70 \\
& 80 & MA80 & A80 \\
\multirow{2}{*}{ Whole peel } & 70 & MP70 & P70 \\
& 80 & MP80 & P80 \\
\hline
\end{tabular}

\section{Results and Discussion}

The drying kinetics of yellow passion fruit albedo (white part) and whole peel was studied as influenced by the drying temperature and maceration process. The temperatures used in the drying were 70 and $80 \pm 1{ }^{\circ} \mathrm{C}$ and the times required for mass equilibrium as well as mass yield of the samples are described in Table 3 . In all samples, the mass loss was very expressive after drying, as expected.

Table 3. Drying times required for mass stabilization and mass yield of passion fruit albedo and peel samples after drying at 70 and $80 \pm 1^{\circ} \mathrm{C}$

\begin{tabular}{lll}
\hline Sample & Time $(\mathrm{min})$ & Yield $(\%)$ \\
\hline A70 & 1860 & 7.20 \\
MA70 & 1380 & 6.49 \\
P70 & 1920 & 10.07 \\
MP70 & 1440 & 6.98 \\
A80 & 1260 & 7.02 \\
MA80 & 780 & 5.94 \\
P80 & 1260 & 9.92 \\
MP80 & 840 & 6.97 \\
\hline
\end{tabular}


Cristo et al. (2018) elaborated flour with the watermelon peel to produce cupcakes and obtained a lower yield than the peel and passion fruit albedo of this work, of only $5 \%$, a value that approximates only the flour made with the macerated and dry albedo at $80{ }^{\circ} \mathrm{C}$. Vieira et al. (2017) elaborated flour with melon bark also for cupcakes production and obtained a yield of $8.8 \%$, lower only than that found in the flour obtained from the integral shell of dried passion fruit at 70 and $80{ }^{\circ} \mathrm{C}$. Freitas et al. (2017) elaborated flours with green bananas of the varieties silver and nanicão for the production of honey loaves and they describe that the final yield of the flour was $17 \%$, higher than those of this research, certainly because the authors used the pulp of the fruit. Santos et al. (2015) conducted eight treatments for the flour processing using different parts and maturation stages of the banana banana, being: a) green banana pulp; b) mature banana pulp; c) green banana peel; d) ripe banana peel; e) pulp plus bark of green banana; f) pulp plus ripe banana peel and g) pulp plus green banana peel without sanitizing with sodium hypochlorite and obtained yields of $39.4 ; 23.81 ; 8.67 ; 11.24 ; 23.34 ; 25.67$ and $23.13 \%$ for flour a, b, c, d, e, f and g respectively, it was observed that when using the fruit pulp in the flour preparation the yields were higher. However, for the flours $\mathrm{c}$ and $\mathrm{d}$ (which were made with only peel), the results approximate the values of the dried passion fruit peel flour at $70{ }^{\circ} \mathrm{C}$ and the $80^{\circ} \mathrm{C}$.

In relation to the drying temperature, samples dried at $80{ }^{\circ} \mathrm{C}$ reached equilibrium in a shorter time than those dried at $70{ }^{\circ} \mathrm{C}$. This is expected, due to the temperature increase of $10{ }^{\circ} \mathrm{C}$, which causes the water to evaporate faster from the samples (Baptestini et al., 2017; Corrêa et al., 2017; Ferreira \& Pena, 2010). Regarding maceration, it was observed that this process contributed to accelerating the drying, possibly because the samples contain higher contents of free water. In addition, water in the maceration process causes bound particles to detach, facilitating mass loss.

Silva et al. (2016), studying the production and characterization of passion fruit albedo flour for food use, observed that the kinetic equilibrium in macerated albedo drying was reached after 1290, 930, 690 and 570 min with the temperatures of $50,60,70$ and $80^{\circ} \mathrm{C}$, respectively. These periods were shorter than those observed in the present study for albedo samples macerated at the same temperatures; double the time was required for the sample dried at $70{ }^{\circ} \mathrm{C}$ and an additional time of 210 min was required for the sample dried at $80{ }^{\circ} \mathrm{C}$. This difference can be explained by the quantity of sample used by these authors in the drying $(200 \mathrm{~g})$ and the device used (tray dryer).

Ferreira and Pena (2010) and Spoladore et al. (2014) conducted drying experiments with passion fruit peel and also obtained equilibrium in shorter period. 530 and $390 \mathrm{~min}$ were required for the temperature of $70{ }^{\circ} \mathrm{C}$, whereas only 475 and $300 \mathrm{~min}$ were required for $80^{\circ} \mathrm{C}$, respectively. The mass used by Ferreira and Pena (2010) was $500 \mathrm{~g}$, which once again reveals that the larger the mass used in the drying of a product, the longer the time required for it to reach equilibrium, considering that the material is arranged on the trays for drying with similar thicknesses. Spoladore et al. (2014) did not describe the mass used in their study, but it was probably even smaller.

Yield values were very low, ranging only from $5.94 \%$ for sample of albedo macerated and dried at $80{ }^{\circ} \mathrm{C}$ to $10.07 \%$ for the sample of peel dried at $70{ }^{\circ} \mathrm{C}$. Such low yield was due to the high moisture content (89.77-94.24\%). It was evident that samples dried at the highest temperature $\left(80^{\circ} \mathrm{C}\right)$ obtained lower yield, since water loss is higher in this case. The samples with highest yield are those of peels with no removal of flavedo (yellow part) and which had not undergone maceration. By contrast, the samples with lowest yield were those composed of only albedo and which had undergone maceration, indicating that this process contributed to mass loss in the product.

Table 4 presents the parameters of the mathematical models of Page, Silva et alii, Henderson \& Pabis and Logarithmic, respectively. 
Table 4. Parameters obtained by fitting Page, Silva et alii, Henderson \& Pabis and Logarithmic models to the experimental drying data of passion fruit albedo and whole peel

\begin{tabular}{|c|c|c|c|c|c|}
\hline \multicolumn{6}{|l|}{ Page } \\
\hline \multirow{2}{*}{ Sample } & \multicolumn{3}{|c|}{ Parameters } & \multirow{2}{*}{$\mathrm{R}^{2}$} & \multirow{2}{*}{$\chi^{2}$} \\
\hline & $\mathrm{a}$ & & $\mathrm{b}$ & & \\
\hline A70 & 0.0003 & & 1.3719 & 0.999 & 0.0028 \\
\hline MA70 & 0.0001 & & 1.5813 & 0.998 & 0.0138 \\
\hline P70 & 0.0005 & & 1.3169 & 0.999 & 0.0063 \\
\hline MP70 & 0.0001 & & 1.5432 & 0.998 & 0.0143 \\
\hline A 80 & 0.0003 & & 1.4854 & 0.999 & 0.0065 \\
\hline MA80 & 0.0002 & & 1.5697 & 0.996 & 0.0193 \\
\hline P80 & 0.0005 & & 1.3479 & 0.999 & 0.0048 \\
\hline MP80 & 0.0002 & & 1.5353 & 0.998 & 0.0106 \\
\hline \multicolumn{6}{|c|}{ Silva et alii } \\
\hline \multirow{2}{*}{ Sample } & \multicolumn{3}{|c|}{ Parameters } & \multirow{2}{*}{$\mathrm{R}^{2}$} & \multirow{2}{*}{$\chi^{2}$} \\
\hline & $\mathrm{a}$ & & $\mathrm{b}$ & & \\
\hline A70 & 0.0040 & & -0.0198 & 0.997 & 0.0296 \\
\hline MA70 & 0.0047 & & -0.0269 & 0.991 & 0.0742 \\
\hline P70 & 0.0041 & & -0.0178 & 0.997 & 0.0280 \\
\hline MP70 & 0.0048 & & -0.0260 & 0.991 & 0.0699 \\
\hline A 80 & 0.0055 & & -0.0270 & 0.994 & 0.0445 \\
\hline MA80 & 0.0059 & & -0.0289 & 0.985 & 0.0756 \\
\hline P80 & 0.0051 & & -0.0212 & 0.996 & 0.0272 \\
\hline \multicolumn{6}{|c|}{ Table 4 (Cont.) } \\
\hline MP80 & 0.0056 & & -0.0282 & 0.989 & 0.0580 \\
\hline \multicolumn{6}{|c|}{ Henderson \& Pabis } \\
\hline \multirow{2}{*}{ Sample } & \multicolumn{3}{|c|}{ Parameters } & \multirow{2}{*}{$\mathrm{R}^{2}$} & \multirow{2}{*}{$\chi^{2}$} \\
\hline & $\mathrm{a}$ & & $\mathrm{b}$ & & \\
\hline A70 & 1.0670 & & 0.0031 & 0.992 & 0.0694 \\
\hline MA70 & 1.0877 & & 0.0034 & 0.982 & 0.1426 \\
\hline P70 & 1.0590 & & 0.0032 & 0.994 & 0.0582 \\
\hline MP70 & 1.0823 & & 0.0035 & 0.984 & 0.1315 \\
\hline A80 & 1.0809 & & 0.0041 & 0.987 & 0.0939 \\
\hline MA80 & 1.0822 & & 0.0042 & 0.974 & 0.1324 \\
\hline P80 & 1.0633 & & 0.0040 & 0.992 & 0.0585 \\
\hline MP80 & 1.0831 & & 0.0041 & 0.979 & 0.1127 \\
\hline \multicolumn{6}{|c|}{ Logarithmic } \\
\hline \multirow{2}{*}{ Sample } & \multicolumn{3}{|c|}{ Parameters } & \multirow{2}{*}{$\mathrm{R}^{2}$} & \multirow{2}{*}{$\chi^{2}$} \\
\hline & $\mathrm{a}$ & $\mathrm{B}$ & $\mathrm{c}$ & & \\
\hline A70 & 1.0960 & 0.0028 & -0.0377 & 0.993 & 0.0518 \\
\hline MA70 & 1.1511 & 0.0029 & -0.0783 & 0.985 & 0.1021 \\
\hline P70 & 1.0836 & 0.0030 & -0.0322 & 0.994 & 0.0434 \\
\hline MP70 & 1.1350 & 0.0030 & -0.0650 & 0.986 & 0.0978 \\
\hline A 80 & 1.1272 & 0.0036 & -0.0580 & 0.989 & 0.0692 \\
\hline MA80 & 1.2654 & 0.0030 & -0.2106 & 0.984 & 0.0664 \\
\hline P80 & 1.1061 & 0.0035 & -0.0545 & 0.994 & 0.0381 \\
\hline MP80 & 1.2375 & 0.0030 & -0.7978 & 0.988 & 0.0547 \\
\hline
\end{tabular}

Note. A70: albedo dried at $70{ }^{\circ} \mathrm{C}$; MA70: macerated albedo dried at $70{ }^{\circ} \mathrm{C}$; P70: peel dried at $70{ }^{\circ} \mathrm{C}$; MP70: macerated peel dried at $70{ }^{\circ} \mathrm{C}$; A80: albedo dried at $80{ }^{\circ} \mathrm{C}$; MA80: macerated albedo dried at $80{ }^{\circ} \mathrm{C}$; P80: peel dried at $80{ }^{\circ} \mathrm{C}$; MP80: macerated peel dried at $80^{\circ} \mathrm{C}$. 
Samples constituted of whole peel without maceration and dried at $70{ }^{\circ} \mathrm{C}$ showed the best results of $\mathrm{R}^{2}$ and good results of $\chi^{2}$ for all models studied. Based on the parameter $\mathrm{R}^{2}$, the Page model fitted best to the experimental data because, for all samples, it showed values higher than 0.990; the lowest value was observed for the albedo macerated and dried at $80{ }^{\circ} \mathrm{C}, 0.996$, which is close to the best results obtained with the model of Silva et al. (2014). The lowest value of $\mathrm{R}^{2}(0.974)$ was obtained with the model of Henderson and Pabis in the sample of albedo macerated and dried at $80^{\circ} \mathrm{C}$.

Menezes et al. (2013), studying the drying kinetics and fitting of mathematical model to the experimental drying data of yellow passion fruit bagasse, also found that the Page's equation was the best model for the data obtained within the temperature range from 35 to $65^{\circ} \mathrm{C}$ and air flow speeds of $0.8,1.0$ and $1.3 \mathrm{~m} \mathrm{~s}^{-1}$. In the present study, the Page model showed $\mathrm{R}^{2}$ above 0.997 , whereas the determination coefficient $\mathrm{R}^{2}$ was close to 0.996 for the logarithmic model and to 0.995 for the Henderson \& Pabis model.

Spoladore et al. (2014) analyzed the mathematical modeling of passion fruit peel drying kinetics and temperature influence on color, phenolic compounds and antioxidant activity, and obtained $\mathrm{R}^{2}$ values of $0.996,0.996,0.996$ and 0.998 for the Page model at temperatures of $60,70,80$ and $90{ }^{\circ} \mathrm{C}$, respectively. For the Henderson \& Pabis model, these values were $0.993,0.992,0.991$ and 0.986 respectively at these same temperatures.

The consulted literature indicates that, for a model to adequately fit to the experimental data, it is essential that $\mathrm{R}^{2}$ be higher than 0.99 and chi-square $\left(\chi^{2}\right)$ be as low as possible. Again, Page model was the one which fitted best to the analyzed data and the highest $\chi^{2}$ value $(0.0193)$ was obtained in the sample of albedo macerated and dried at $80{ }^{\circ} \mathrm{C}$.

Henderson \& Pabis model (Table 4) was the furthest from a good fit to the experimental data, especially in the sample of albedo macerated and dried at $80{ }^{\circ} \mathrm{C}$, with $\mathrm{R}^{2}$ of 0.9737 and $\chi^{2}$ of 0.1324 .

Silva et alii and logarithmic models showed similar values, but the former was the better of the two, because it has fewer data-fitting parameters. The best values of $\mathrm{R}^{2}$ and $\chi^{2}$ for Silva et alii model were observed in the drying of albedo and peel at $70{ }^{\circ} \mathrm{C}: \mathrm{R}^{2}=0.996833$ and 0.996979 , and $\chi^{2}=0.0296$ and 0.0281 , respectively.

Silva et alii, assessing mathematical models to describe thin-layer drying and determine the drying rate of whole bananas, after drying at $70{ }^{\circ} \mathrm{C}$, obtained $\mathrm{R}^{2}$ of 0.999 and $\chi^{2}$ of $1.35 \times 10^{-3}$. In the present study, the best result found using the Silva et alii model was $\mathrm{R}^{2}$ of 0.996979 for the drying of passion fruit peel at $70^{\circ} \mathrm{C}$.

With the Logarithmic model, the drying of passion fruit peel at $70{ }^{\circ} \mathrm{C}$ also stood out as the best, showing $\mathrm{R}^{2}$ and $\chi^{2}$ of 0.994 and 0.0434 , respectively.

After analyzing the statistical indicators obtained, Page model was selected to represent the graphs of drying kinetics as influenced by temperature, shown in Figure 3.

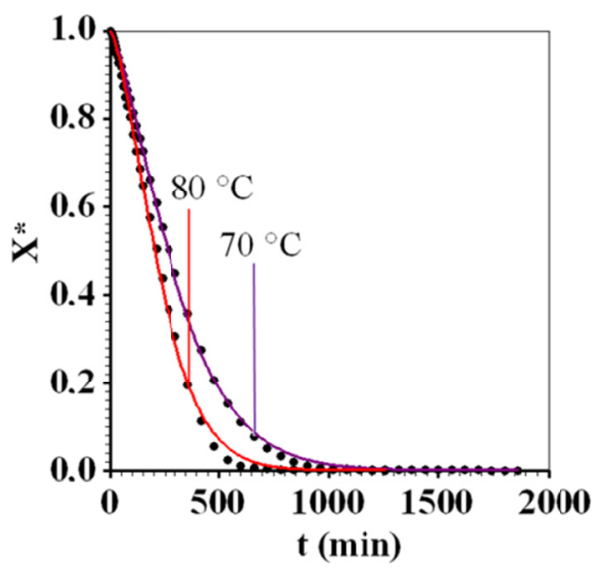

(a)

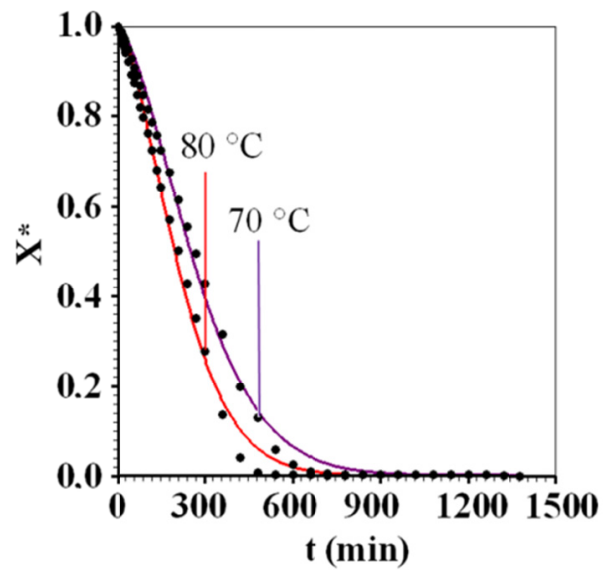

(b) 


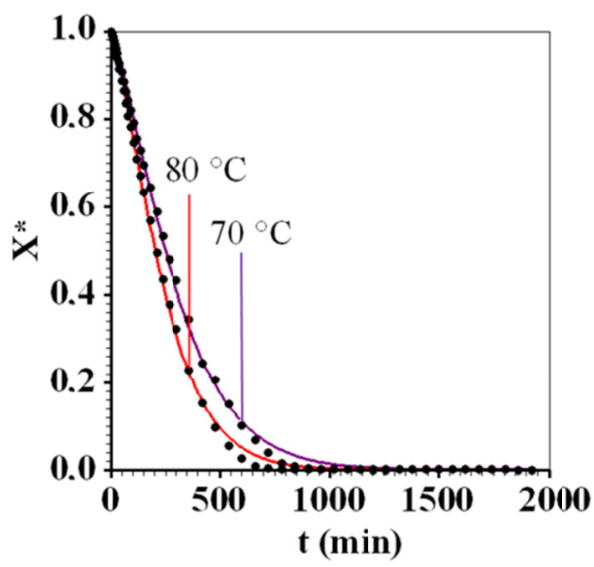

(c)

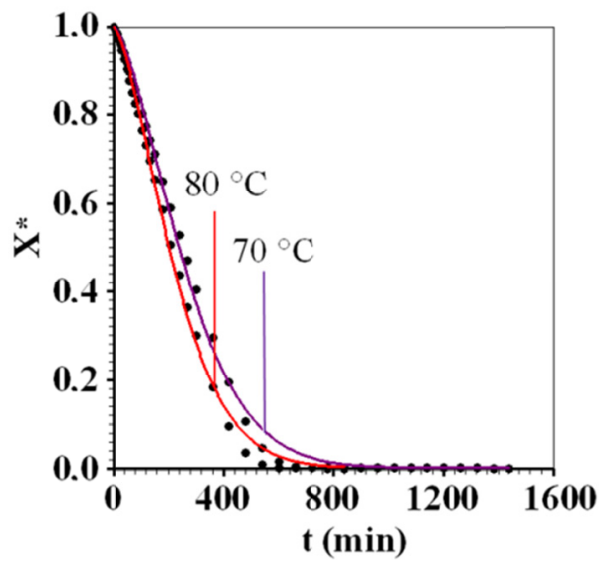

(d)

Figure 3. Passion fruit drying kinetics at 70 and $80{ }^{\circ} \mathrm{C}$ using Page model for: (a) albedo; (b) macerated albedo; (c) peel; (d) macerated peel

By analyzing all graphs in Figure 3, it can be noted that samples dried at $70{ }^{\circ} \mathrm{C}$ required longer time to reach equilibrium, in all cases. Visually, Page model fitted well to the experimental points at the temperature of $80^{\circ} \mathrm{C}$ (Figure 3), except for the sample of macerated albedo (Figure 3(b)), in which the points were more dispersed around the respective experimental data. For the temperature of $70^{\circ} \mathrm{C}$, Page model fitted best to the observed data in Figure 3(a), relative to the sample of passion fruit albedo.

The influence of maceration on the drying kinetics is presented in Figures 4 and 5. In all cases shown in Figure 4 and 5 , the maceration process tends to reduce the drying time. However, the experimental points showed slightly greater dispersion in the macerated samples. Visually, the best fits were observed in Figure 4(a), relative to albedo with and without maceration dried at temperature of $70^{\circ} \mathrm{C}$.

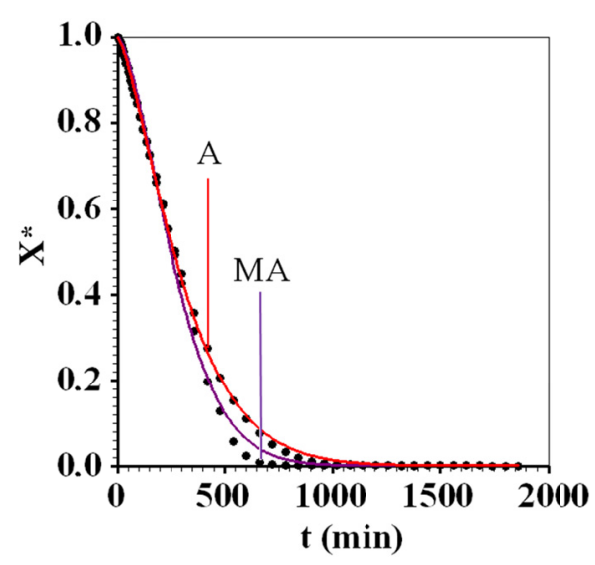

(a)

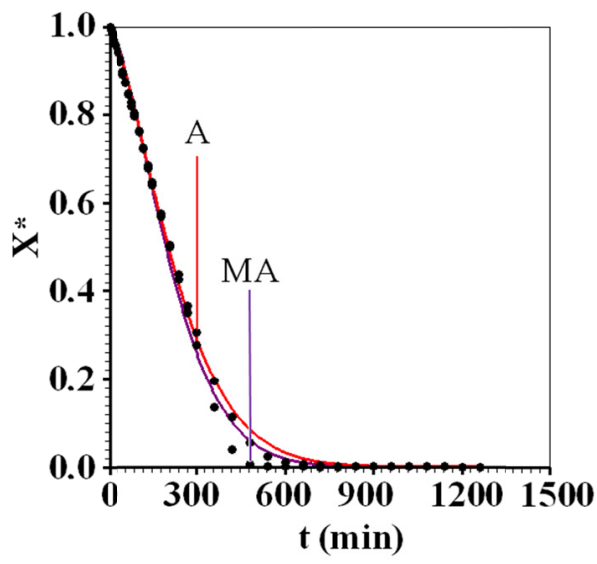

(b)

Figure 4. Passion fruit drying kinetics using Page model for: (a) albedo with and without maceration at $70{ }^{\circ} \mathrm{C}$; (b) albedo with and without maceration at $80^{\circ} \mathrm{C}$ 


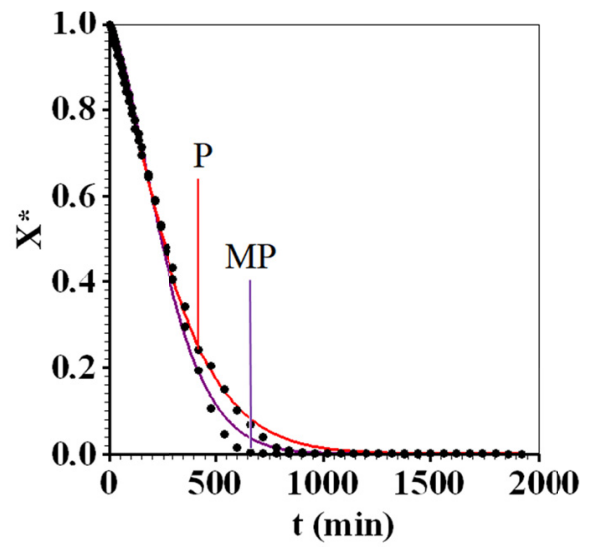

(a)

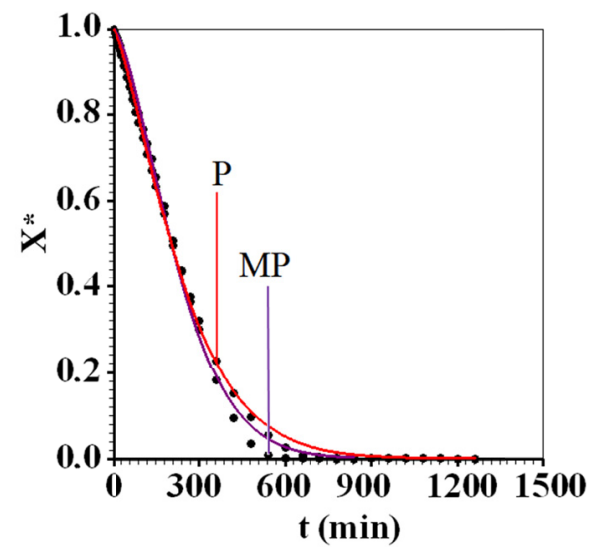

(b)

Figure 5. Passion fruit drying kinetics using Page model for: (a) peel with and without maceration at $70{ }^{\circ} \mathrm{C}$; (b) peel with and without maceration at $80^{\circ} \mathrm{C}$

\section{Conclusion}

The mass yield of the samples after drying can be considered as low and the best result was $10.07 \%$.

The mathematical model of Page was the one which fitted best to the experimental data of drying for all samples. It can also be highlighted that the sample composed of peel without maceration and dried at $70{ }^{\circ} \mathrm{C}$ had the best results of $\mathrm{R}^{2}$, besides adequate values of $\chi^{2}$ in the four models.

Both the increase in drying temperature (from 70 to $80^{\circ} \mathrm{C}$ ) and the maceration process reduced the drying time, but the increase of temperature was the preponderant factor.

\section{Acknowledgement}

The second author would like to thank CNPq (Conselho Nacional de Desenvolvimento Científico e Tecnológico) for supporting this study and for his research grant (Process Number 302480/2015-3).

\section{References}

Baptestini, F. M., Corrêa, P. C., Oliveira, G. H. H. De, Botelho, F. M., \& Oliveira, A. P. L. de. (2017). Heat and mass transfer coefficients and modeling of infrared drying of banana slices. Revista Ceres, 64, 457-464. https://doi.org/10.1590/0034-737x201764050002

Corrêa, P. C., Baptestini, F. M., Bustos-Vanegas, J. D., Freitas, R. L., Botelho, F. M., \& Oliveira, G. H. H. (2017). Kinetics of water sorption of damaged bean grains: Thermodynamic properties. Revista Brasileira de Engenharia Agrícola e Ambiental, 21, 556-561. https://doi.org/10.1590/1807-1929/agriambi.v21n8 p556-561

Cristo, T. W., Santos, M. M. R., Candido, C. J., Santos, E. F., \& Novello, D. (2018). Cupcake com adição de farinha de casca de melancia (Citrullus lanatus): caracterização físico-química e sensorial. Ambiência, 14(2), 331-342.

Di Domenico, C. N. B., \& Conrad, T. M. (2015). Simulação de processos de secagem através dos modelos matemáticos exponencial e de Page. Vivências: Revista Eletrônica de Extensão da URI, 11, 134-146.

Di Domenico, C. N. B., Silva, F. J. N., \& Ferreira, J. A. F. O. (2017). uso de redes neurais artificiais na otimização do processo de secagem convectiva de alimentos e redução do consumo energético. Ágora Revista Eletrônica, 24, 90-108.

Dias, M. V., Figueiredo, L. P., Valente, W. A., Ferrua, F. Q., Pereira, P. A. P., Pereira, A. G. T., ... Clemente, P. R. (2011). Estudo de variáveis de processamento para produção de doce em massa da casca do maracujá (Passiflora edulis f. Flavicarpa). Ciência e Tecnologia de Alimentos, 31, 65-71. https://doi.org/10.1590/ S0101-20612011000100008

Dias, M. V., Figueiredo, L. P., Valente, W. A., Ferrua, F. Q., Pereira, P. A. P., Pereira, A. G. T., ... Clemente, P. R. (2011). Estudo de variáveis de processamento para produção de doce em massa da casca do maracujá (Passiflora edulis f. Flavicarpa). Ciência e Tecnologia de Alimentos, 31, 65-71. 
Ferreira, M. F. P., \& Pena, R. S. (2010). Estudo da secagem da casca do maracujá amarelo. Revista Brasileira de Produtos Agroindustriais, 12, 15-28. https://doi.org/10.15871/1517-8595/rbpa.v12n1p15-28

Freitas, M. C. J., Silveira, G. E. S., Veras, L. S., \& Santos, G. F. F. (2017). Pães de mel elaborados com farinha de diferentes variedades de banana verde. Demetra, 12(2), 465-482. https://doi.org/10.12957/demetra.2017. 25127

Henderson, S. M., \& Pabis, S. (1961). Grain drying theory I. Temperature effect on drying coefficient. Journal of Agriculture Engineering Research, 6, 169-174.

Machado, M. P., Bergo, C. L., Deschamps, C., Bizzo, H. R., \& Biasi, L. A. (2013). Efeito da secagem natural e artificial da biomassa foliar de Piper hispidinervum na composição química do óleo essencial. Semina: Ciências Agrárias, 34, 265-270. https://doi.org/10.5433/1679-0359.2013v34n1p265

Menezes, M. L., Ströher, A. P., Pereira, N. C., \& Barros, S. T. D. (2013). Análise da cinética e ajustes de modelos matemáticos aos dados de secagem do bagaço do maracujá-amarelo. Engevista, 15, 176-186. https://doi.org/10.22409/engevista.v15i2.443

Page, G. E. (1949). Factors influencing the maximum of air drying shelled corn in thin layer (Thesis Master's, Purdue University, India).

Santos, L. F., Lehner, M. T., Freitas, A. F., \& Ries, E. F. (2015). Caracterização de farinhas de banana caturra e utilização em biscoito dietético. Magistra, 27(2), 145-158.

Silva, E. C. O., Silva, W. P., Silva, E. T., Lopes, J. D., \& Gusmão, R. P. (2016). Obtenção e caracterização da farinha do albedo de maracujá (Passiflora edulis f. Flavicarpa) para uso alimentício. Revista Verde de Agroecologia e Desenvolvimento Sustentável, 11, 69-74. https://doi.org/10.18378/rvads.v11i3.4062

Silva, E. S., Oliveira, J., Machado, A. V., \& Costa, R. O. (2015). Secagem de grãos e frutas: Revisão bibliográfica. Revista Brasileira de Agrotecnologia, 5, 19-23.

Silva, W. P., Silva, C. M. D. P. S., Gama, F. J. A., \& Gomes, J. P. (2014). Mathematical models to describe thin-layer drying and to determine drying rate of whole bananas. Journal of the Saudi Society of Agricultural Sciences, 13, 67-74. https://doi.org/10.1016/j.jssas.2013.01.003

Spoladore, S. F., Bissaro, C. A., Vieira, T. F., Silva, M. V., Haminiuk, C. W. I., \& Demczuk Junior, B. (2014). Modelagem matemática da secagem de casca de maracujá e influência da temperatura na cor, compostos fenólicos e atividade antioxidante. Revista Brasileira de Pesquisa em Alimentos, 5, 17-25. https://doi.org/ 10.14685/rebrapa.v5i2.163

Vieira, R. F. F. A., Carvalho, C. L. S., Carvalho, I. R. A., Candido, C. J., Santos, E. F., \& Novello, D. (2017). Adição de farinha da casca de melão em cupcakes altera a composição físico-química e a aceitabilidade entre crianças. Conexão Ciência, 12(2), 22-30. https://doi.org/10.24862/cco.v12i2.611

Yaldiz, O., Ertekin, C., \& Uzun, H. I. (2001). Mathematical modeling of thin-layer solar drying of sultana grapes. Energy, 26, 457-465. https://doi.org/10.1016/S0360-5442(01)00018-4

Yamashita, B. B. V. G. (2017). Extração sequencial de compostos fenólicos e pectina da casca da manga assistida por ultrassom (p. 115, Dissertação Mestrado, UFRGS, Porto Alegre).

\section{Copyrights}

Copyright for this article is retained by the author(s), with first publication rights granted to the journal.

This is an open-access article distributed under the terms and conditions of the Creative Commons Attribution license (http://creativecommons.org/licenses/by/4.0/). 